\title{
Pengaruh Tingkat Penambahan Tepung Daun Singkong dalam Ransum Komersial terhadap Bobot Ampela, Jantung dan Hati Broiler Strain CP 707
}

\author{
Nilawati Widjaya \\ Jurusan Produksi Ternak, Fakultas Pertanian, Universitas Bandung Raya \\ Jl. Banten No 11. Bandung, 40272 \\ Email:widjajanilawati@yahoo.com
}

\begin{abstract}
ABSTRAK
Penelitian bertujuan untuk mengetahui pengaruh tingkat penambahan tepung daun singkong dalam ransum komersial terhadap bobot ampela, jantung dan hati broiler strain CP 707 serta mengetahui penambahan tepung daun singkong yang menghasilkan bobot ampela, jantung dan hati broiler yang paling tinggi. Metode penelitian adalah eksperimen menggunakan Rancangan Acak Lengkap (RAL) dengan perlakuan 5 macam ransum, yaitu 100\% ransum komersial (R0), 96\% ransum komersial ditambah 4\% tepung daun singkong (R1), 92\% ransum komersial ditambah 8\% tepung daun singkong (R2), 88\% ransum komersial ditambah 12\% tepung daun singkong (R3), 84\% ransum komersial ditambah 16\% tepung daun singkong (R4). Setiap perlakuan diulang 5 kali. Peubah yang diamati yaitu bobot ampela, jantung dan hati. Data dianalisis dengan sidik ragam, apabila terdapat pengaruh perlakuan dilanjutkan dengan Uji Jarak Berganda Duncan's. Hasil penelitian menunjukkan bahwa penambahan tepung daun singkong dalam ransum komersial berpengaruh terhadap bobot ampela dan jantung, namun tidak berpengaruh terhadap bobot hati broiler strain CP 707, bobot ampela dan jantung tertinggi diperoleh dari broiler strain CP 707 yang mengkonsumsi 84\% ransum komersial dengan penambahan tepung daun singkong sebanyak $16 \%$.
\end{abstract}

Kata kunci: broiler, daun singkong, ampela, jantung, hati

\section{Effect of the Addition of Cassava Leaf Meal in Rations Commercial against Gizzard Weight, Heart and Liver of Broiler Strain CP 707}

\begin{abstract}
The objective of the research was to determine the effect of cassava leaf meal addition in commercial diets on weight of gizzard, heart and liver of broiler strains CP 707 and find out the addition level which produced the highest weight of gizzard, heart and liver of broilers. The experiment used Completely Randomized Design with 5 dietary treatments, namely 100\% commercial ration (R0), 96\% commercial diet plus 4\% cassava leaf meal (R1), 92\% commercial diet plus 8\% cassava leaf meal (R2), 88\% commercial diet plus 12\% cassava leaf meal (R3), 84\% commercial diet plus 16\% cassava leaf meal (R4). Each treatment was repeated 5 times. Variables measured were the weight of gizzard, heart and liver. Data were analyzed with ANOVA and followed by Duncan's Multiple Range Test. The addition of cassava leaf meal in commercial ration influenced weight of gizzard and heart, but did not affect liver weight. The highest weight of gizzard and heart obtained from broilers consumed $84 \%$ commercial diet with the addition of cassava leaf meal as much as $16 \%$.
\end{abstract}

Key words: broiler, cassava leaf meal, gizzard, heart, liver 


\section{PENDAHULUAN}

Ransum merupakan faktor penting yang besar pengaruhnya terhadap produksi ternak, ransum berkualitas tinggi hendaknya memenuhi syarat dalam arti mengandung zat-zat yang diperlukan dalam keseimbangan yang tepat. Harga ransum yang berkualitas semakin tinggi, akibatnya banyak peternak yang beralih ke produk ransum yang lebih terjangkau, namun tidak menghasilkan pertumbuhan yang optimal bagi broiler. Salah satu cara menghasilkan ransum yang berkualitas dan terjangkau, perlu ada pencampuran bahan ransum yang memiliki protein kasar yang tinggi, selain itu bahan ransum tersebut harus mudah diperoleh secara kontinyu. Salah satu upaya yang bisa dilakukan adalah dengan mencampurkan tepung daun singkong dengan ransum komersial.

Tepung daun singkong dapat menjadi bahan ransum yang tepat untuk dicampur dengan ransum komersial, mengingat kandungan protein kasar yang terdapat dari tepung daun singkong sangat tinggi sehingga dapat mempercepat pertumbuhan, selain itu tepung daun singkong dapat diperoleh dengan mudah. Kelebihan tepung daun singkong lainnya adalah memiliki serat kasar yang tinggi, sehingga dapat mempengaruhi bobot ampela, jantung dan hati. Di Indonesia, ampela, jantung dan hati merupakan salah satu bahan pangan dan harganya cukup tinggi, sehingga dengan bobot ampela, jantung dan hati yang tinggi, akan menghasilkan keuntungan yang optimal bagi usaha ternak broiler.

Permasalahan pada tepung daun singkong adalah memiliki asam sianida (HCN) yang beracun bagi ternak. Asam sianida ini tersebar merata dipermukaan daun, dengan adanya metionin dalam ransum asam sianida hasil hidrolisis linamarin dan luteustralin akan mengalami detoksifikasi. Asam sianida mempunyai sifat mudah larut dan mudah menguap, oleh karena itu untuk menurunkan atau mengurangi kadar asam sianida dapat dilakukan dengan perendaman dan pengeringan karena asam sianida akan larut dan ikut terbuang dengan air

Penggunaan broiler sebagai objek penelitian sangat relevan bila dikaitkan dengan perlakuan pemberian ransum, mengingat broiler memiliki sifat pertumbuhan relatif singkat sehingga lebih resposif terhadap adanya perlakuan. Berdasarkan hal tersebut maka dilakukan penelitian mengenai Pengaruh Tingkat Penambahan Tepung Daun Singkong dalam Ransum Komersil Terhadap Bobot Ampela, Jantung dan Hati Broiler Strain CP 707.

\section{MATERI DAN METODE}

Penelitian ini menggunakan broiler strain CP 707, jumlah broiler yang digunakan sebanyak 100 ekor tanpa pemisahan jenis kelamin atau straight run, gula pasir, antibiotik, air minum, ransum, desinfektan, litter menggunakan sekam padi. Alat yang digunakan dalam penelitian ini adalah kandang beralaskan litter sebanyak 25 petak kandang yang terbuat dari kayu, induk buatan dari kayu dengan menggunakan lampu pijar 15 watt, tempat ransum, timbangan digital, galon air, thermometer, pisau.

Rancangan percobaan yang digunakan adalah rancangan acak lengkap (RAL) dengan 5 perlakuan susunan ransum dan diulang sebanyak lima kali. Data yang dihimpun bobot ampela, jantung, dan hati dalam satuan gram. Data yang diperoleh dianalisis dengan menggunakan sidik ragam dengan uji $F$ untuk mengetahui pengaruh perlakuan. Bila ada pengaruh perlakuan yang berbeda nyata, maka dilanjutkan dengan Uji Wilayah Berganda Duncan's (Steel dan Torie, 1991).

\section{HASIL DAN PEMBAHASAN}

Rata-rata bobot ampela, jantung dan hati ayam broiler pada masing-masing perlakuan selama percobaan dapat dilihat pada Tabel 1. 
Tabel 1. Rataan bobot ampela, jantung dan hati broiler pada nasing-masing perlakuan selama percobaan.

\begin{tabular}{cccc}
\hline Perlakuan & Bobot Ampela (g) & Bobot Jantung (g) & Bobot Hati (g) \\
\hline R0 & $28,00^{\mathrm{a}}$ & $9,20^{\mathrm{a}}$ & 39,20 \\
R1 & $35,20^{\mathrm{b}}$ & $10,20^{\mathrm{b}}$ & 39,40 \\
R2 & $35,40^{\mathrm{b}}$ & $10,20^{\mathrm{b}}$ & 39,60 \\
R3 & $36,00^{\mathrm{b}}$ & $10,40^{\mathrm{b}}$ & 43,00 \\
R4 & $36,20^{\mathrm{b}}$ & $10,60^{\mathrm{b}}$ & 43,40 \\
\hline
\end{tabular}

${ }^{\mathrm{a}, \mathrm{b}}$ Huruf yang berbeda pada kolom yang sama menunjukkan perbedaan yang nyata $(\mathrm{P}<0,05)$.

Dari Tabel 1 dapat dilihat rataan bobot ampela tertinggi ditunjukkan oleh broiler yang diberi ransum $\mathrm{R} 4 \quad(84 \%$ ransum komersial dengan penambahan $16 \%$ tepung daun singkong) sebesar 36.20 gram, diikuti dengan broiler yang mengkonsumsi ransum R3 (88\% ransum komersial dengan penambahan $12 \%$ tepung daun singkong) sebesar 36.00 gram, kemudian broiler yang mengkonsumsi ransum R2 $(92 \%$ ransum komersial dengan penambahan 8\% tepung daun singkong) sebesar 35.40 gram, lalu R1 (96\% ransum komersial dengan penambahan $4 \%$ tepung daun singkong) sebesar 35.20 gram dan terendah broiler yang mengonsumsi ransum R0 (100\% ransum komersial) sebesar 28.00 gram. Berdasarkan analisis ragam diketahui bahwa perlakuan berpengaruh nyata $(\mathrm{P}<0.05)$ terhadap bobot ampela. Rataan bobot ampela pada broiler yang diberi ransum R1, R2, R3 dan R4 nyata lebih besar dari broiler yang diberi ransum R0.

Adanya perbedaan besaran bobot ampela tersebut diduga disebabkan kandungan serat kasar yang tinggi pada ransum R1,R2,R3, dan R4. Kandungan serat kasar yang tinggi pada ransum akan mengakibatkan kerja ampela semakin meningkat. Hal ini akan menyebabkan otototot ampela semakin tebal sehingga bobot ampela meningkat. Sejalan dengan pendapat Deaton et al. (1977) bahwa bobot ampela akan meningkat seiring dengan meningkatnya serat kasar dalarn ransum. Hal ini disebabkan oleh meningkatnya kontraksi ampela saat mencerna serat kasar. Sundari
(1983), menyatakan besarnya bobot ampela menunjukkan fungsi ampela yang cukup berat dalam menggiling makanan karena kandungan serat kasarnya tinggi. Bobot ampela pada R1,R2,R3 dan R4 berbeda tidak nyata diduga karena kandungan serat kasar pada ransum R1, R2, R3 dan R4 perbedaannya relatif sedikit, sehingga kerja ampela tidak begitu berbeda, oleh karena itu bobot ampelanya tidak berbeda pula.

Rataan bobot jantung tertinggi ditunjukkan oleh broiler yang diberi ransum R4 (84\% ransum komersial dengan penambahan $16 \%$ tepung daun singkong) sebesar 10.60 gram, diikuti dengan broiler yang mengkonsumsi ransum R3 (88\% ransum komersial dengan penambahan $12 \%$ tepung daun singkong) sebesar 10.40 gram, kemudian broiler yang mengkonsumsi ransum R2 (92\% ransum komersial dengan penambahan $8 \%$ tepung daun singkong) dan R1 (96\% ransum komersial dengan penambahan $4 \%$ tepung daun singkong) sebesar 10.20 gram dan terendah broiler yang mengkonsumsi ransum R0 (100\% ransum komersial) sebesar 9.20 gram. Berdasarkan analisis ragam diketahui bahwa perlakuan berpengaruh nyata $(\mathrm{P}<0.05)$ terhadap bobot jantung. Rataan bobot jantung pada broiler yang diberi ransum R1, R2, R3 dan R4 nyata lebih besar dari broiler yang diberi ransum R0.

Adanya perbedaan bobot jantung tersebut diduga disebabkan kerja jantung dipengaruhi kerja ampela. Kandungan serat kasar yang tinggi pada R1,R2,R3 dan R4 menyebabkan kerja ampela semakin berat. 
Hal ini akan menyebabkan aliran darah dari jantung mengalir lebih deras, artinya kerja jantung akan menyebabkan otot-ototnya semakin menebal sehingga bobot jantung relatif lebih tinggi. Sejalan dengan pendapat Nabib dan Maidie (1981), jantung dapat bertambah besar jika terjadi dilatasi yaitu pembesaran dari satu atau beberapa ruangan jantung yang disebabkan oleh kelelahan dan hipertopi, yaitu pembesaran jantung yang disertai penebalan dinding ventrikel untuk mengimbangi kebutuhan akan aliran darah. Bobot jantung pada R1,R2,R3 dan R4 berbeda tidak nyata diduga disebabkan kerja ampela yang tidak berbeda dan kandungan serat kasar pada R1,R2,R3 dan R4 perbedaannya hanya sedikit. Kerja ampela yang tidak berbeda, menyebabkan kerja jantung relatif sama, sehingga bobot jantung tidak berbeda.

Rataan bobot hati tertinggi ditunjukkan oleh broiler yang diberi ransum R4 (84\% ransum komersial dengan penambahan $16 \%$ tepung daun singkong) sebesar 43.40 gram, diikuti dengan broiler yang mengkonsumsi ransum R3 (88\% ransum komersial dengan penambahan $12 \%$ tepung daun singkong) sebesar 43.00 gram, kemudian broiler yang mengkonsumsi ransum R2 (92\% ransum komersial dengan penambahan $8 \%$ tepung daun singkong) sebesar 39.60 gram, selanjutnya broiler yang mengkonsumsi ransum R1 $(96 \%$ ransum komersial dengan penambahan $4 \%$ tepung daun singkong) sebesar 39.40 gram dan terendah broiler yang mengkonsumsi ransum R0 (100\% ransum komersial) sebesar 39.20 gram. Berdasarkan analisis ragam diketahui bahwa perlakuan berpengaruh tidak nyata terhadap bobot hati. Hal ini diduga karena kandungan serat kasar dalam ransum percobaan di bawah $8 \%$ masih bisa ditolelir sehingga kerja hati tidak terganggu, oleh karena itu tidak berpengaruh terhadap bobot hati. Sejalan dengan hasil penelitian Akiba dan Matsumoto (1978), bahwa peningkatan serat kasar sampai dengan $8 \%$ di dalam ransum tidak berpengaruh terhadap bobot hati.

\section{KESIMPULAN}

Dari hasil penelitian dapat disimpulkan bahwa penambahan tepung daun singkong dalam ransum komersial berpengaruh terhadap bobot ampela dan jantung, namun tidak berpengaruh terhadap bobot hati broiler strain CP 707, bobot Ampela dan Jantung tertinggi diperoleh dari broiler strain CP 707 yang mengkonsumsi 84\% ransum komersial dengan penambahan tepung daun singkong sebanyak16 \%.

\section{DAFTAR PUSTAKA}

Akiba, M., and T. Matsumoto. 1978. Effect of Force Feeding and Dietary Cellulose on Liver Lipid Accumulation and Lipid Composition on Liver and Plasma in Growing Chick. Jour. Nutr. 108 : 739-748.

Deaton, J, W., L. F. Kubena, F. N. Reece and B. P. ott. 1977. Effect of Dietary Fibre on the Performance of Laying Hens. Br. Poult. Sci. $18:$ 711-714.

Nabib, R., dan M.S. Maidie. 1981. Patologi Khusus Veteriner. Cetakan ke-3. Fakultas Kedokteran Veteriner. IPB Bogor.

Steel, G.D dan J.H.Torrie. 1991. Prinsip dan Prosedur Statistika Suatau Pendekatan Biometrik. Edisi Kedua. Gramedia Pustaka Utama. Jakarta.

Sundari, S.K. 1983. Pengaruh Penggunaan Tepung daun Alang-alang Dalam Ransum Ayam Jantan. Tipe Medium Babcock. Disertasi. Tidak Dipublikasikan. Fakultas Peternakan. IPB Bogor. 